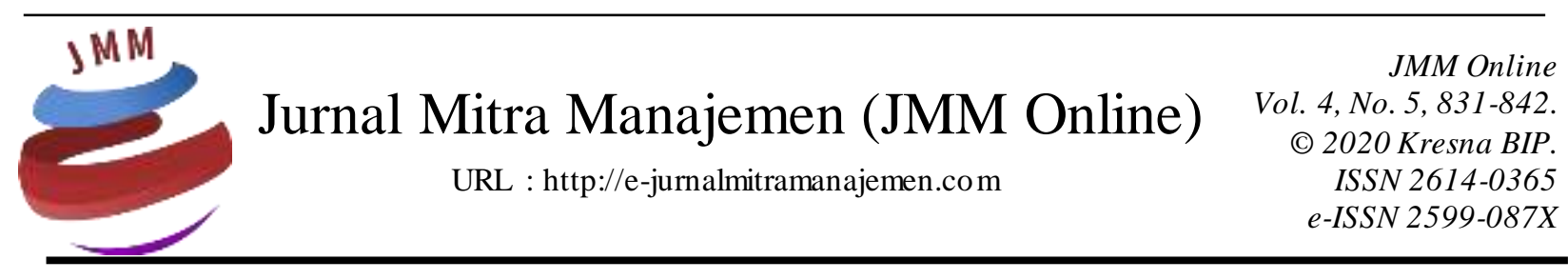

\title{
PENGARUH STRES KERJA TERHADAP KEPUASAN KERJA (STUDI PADA CV FATIH TERANG PURNAMA)
}

\author{
Fagar Fertiwi Fardah 1), Hani Gita Ayuningtias 2) \\ Universitas Telkom
}

\section{INFORMASI ARTIKEL}

Dikirim : 10 Mei 2020

Revisi pertama : 13 Mei 2020

Diterima : 16 Mei 2020

Tersedia online : 20 Mei 2020

Kata Kunci: Stres Kerja, Kepuasan Kerja

Email : fagareeefertiwi@gmail.com ${ }^{1)}$, hanigita@telkomuniversity.ac.id ${ }^{2)}$

\begin{abstract}
ABSTRAK
\end{abstract}
Penelitian ini bertujuan untuk mengetahui tingkat stres, tingkat kepuasan kerja dalam perusahaan dan bagaimana pengaruh stres kerja terhadap kepuasan kerja pada karyawan CV Fatih Terang Purnama. Metode pengumpulan data dalam penelitian ini diperoleh dengan melakukan penyebaran kuisioner terhadap 160 responden dengan jumlah pertanyaan sebanyak 68 dengan skala likert 4 titik. Metode sampling yang digunakan pada penelitian ini menggunakan nonprobability dengan teknik purposive sampling. Dalam menjelasakan hasil penelitian, teknik analisis data yang digunakan adalah anaisis deskriptif dan analisis regresi linier sederhana. Hasil yang diperoleh pada penelitian ini menunjukan bahwa stres kerja berpengaruh signifikan negatif terhadap kepuasan kerja karyawan CV Fatih Terang Purnama. Koefisien determinasi yang didapatkan dengan nilai $R$ square sebesar $43.4 \%$ artinya stres kerja memiliki kontribusi pengaruh terhadap kepuasan kerja. Hasil penelitian ini akan menjadi masukan bagi CV Fatih Terang Purnama untuk selalu mengelola tangkat stress kerja yang bisa dialamai suatu saat oleh karyawan yang dapat menurunkan kepuasan kerja pada masing masing karyawan dalam perusahaan dengan selalu memperhatikan kesejahteraan karyawan. 


\section{PENDAHULUAN \\ Latar Belakang}

Sumber daya manusia merupakan aset yang sangat penting untuk kemajuan suatu organisasi, perusahaan, pemerintahan dan juga dalam menjalankan suatu usaha baik usaha kecil hingga besar. Menurut Mahartika (2019) sumber daya manusia merupakan bagian penting dalam mendirikan perusahaan sehingga perusahaan harus memiliki sumber daya manusia yang berkulitas dan berkompeten untuk membantu organisasi mencapai tujuan. Menurut Praditya (2019) sumber daya yang baik memiliki kualitas dan kontribusi untuk siap bersaing dalam dunia pekerjaan sehingga berdampak pada kinerja yang efesien dan mencapai hasil kerja yang memuaskan bagi organisasi.

Pada zaman yang terus menuntut suatu organisasi selalu berinovasi dan berkembang, salah satu fenomena dalam lingkup perilaku organisasi yang harus diperhatikan salah satunya adalah kepuasan kerja karyawan atau biasa dikenal degan istilah Job Satisfaction. Anjungsoro (2016) mengungkapkan bahwa perusahaan yang memiliki reputasi yang baik memiliki tingkat kepuasan kerja karyawan yang tinggi. Kepuasan kerja adalah suatu perasaan yang berhubungan dengan pekerjaan yang melibatkan beberapa aspek seperti upah, gaji yang didapat, kesempatan dalam pengembangan karir, hubungan atau relasi dengan pegawai lainnya, penempatan kerja, jenis pekerjaan yang diemban, mutu pengawasan yang mendukung atau tidak mendukung kondisi karyawan (Novita et al., 2016).

Terdapat beberapa faktor yang mempengaruhi kepuasan kerja menurut pendapat Salisu et al. (2015) menyatakan bahwa terdapat faktor lain dalam kepuasan kerja yaitu keamanan kerja dan lingkungan kerja. Menurut Daud (2016) yang dapat mempengaruhi kepuasan dalam bekerja adalah kegiatan pekerjaan saat ini, prestasi dan tanggung jawab yang diemban dalam pekerjaan. Ketidak puasan kerja yang dirasakan oleh karyawan akan berdampak negatif bagi perusahaan karena karyawan akan merasa tertekan dengan pekerjaannya dan tidak dapat menyelesaikan pekerjaannya dengan baik sehingga dapat menimbulkan stres kerja Riaz et al. (2016).

Menurut Gilang et al. (2015) stres kerja merupakan tekanan yang dialami oleh setiap orang dalam menjalani kehidupan kerjanya, stres sendiri mengandung dua arti yaitu positif dan negatif tergantung bagaimana seseorang dapat mengatasi stres, dalam pandangan positif secara psikologis akan menumbuhkan motivasi dan semangat kerja sedangkan dalam makna negatif dapat menurunkan tingkat kinerja karyawan. Perusahaan harus mampu meminimalisir stres kerja yang dialami oleh karyawan, sehingga kinerja karyawan semakin memenuhi apa yang menjadi tuntutan pekerjaan Wartono (2017).

Setiap perubahan zaman dari masa ke masa perkebunan akan selalu menjadi hal yang penting dalam kehidupan baik untuk lapangan pekerjaan, roda perekonomian dan juga manfaat dari hasil perkebunan itu sendiri. Menurut Nugraha (2019) perkebunan kelapa sawit memiliki penghasilan yang tinggi hingga tigaratus triliun kepada negara tetapi tidak sebanding dengan kesejahteraan pekerja pada sektor perkebunan ini yang didominasi oleh buruh kerja harian. CV Fatih Terang Purnama merupakan salah satu perusahaan yang mengelola hasil perkebunan kelapa sawit berlokasi di Sekayu, Sumatera Selatan. Perusahaan ini fokus menjadi suplier utama yang berafiliasi dengan PT Bayung Agro Sawita. 
Berdasarkan hasil wawancara dengan direktur CV Fatih Terang Purnama bahwa pekerja yang memiliki tingkat kerja yang paling tinggi adalah divisi akomodasi hasil perkebunan karena memiliki tugas kontak yang paling lama di lapangan. Proses akomodasi yang dilakukan dimulai dengan mengumpulkan kelapa sawit, melakukan timbangan lapangan, memindahkan buah sawit ke dalam truk selanjutnya mendeliverikannya ke PT Bayung Agro Sawita dari setiap daerah yang telah dijadwalkan, kegiatan ini dapat berlangsung selama enam hingga dua belas jam tergantung dengan lokasi dan luas kebun sumber sawit yang dapat dijelaskan oleh tabel berikut:

Tabel 1. Jadwal Kerja Divisi Akomodasi Hasil Tanaman CV Fatih Terang Purnama

\begin{tabular}{|c|c|c|c|c|c|c|c|}
\hline No & Nama & Senin & Selasa & Rabu & Kamis & Jumat & Sabtu \\
\hline 1 & $\begin{array}{l}\text { Ysf } \\
\text { Mhn } \\
\text { Kmn }\end{array}$ & $\begin{array}{l}\text { B1, } \\
\text { Senayar } \\
\text { Jaya }\end{array}$ & $\begin{array}{l}\text { B2, } \\
\text { Sungai } \\
\text { Lilin }\end{array}$ & $\begin{array}{l}\text { B3, } \\
\text { Kayu } \\
\text { Agung }\end{array}$ & $\begin{array}{l}\text { D2, } \\
\text { Babat } \\
\text { Toman }\end{array}$ & Mendis & $\begin{array}{l}\text { Pulau } \\
\text { Gading }\end{array}$ \\
\hline 2 & $\begin{array}{l}\text { Dnn } \\
\text { Bbi } \\
\text { Nru }\end{array}$ & $\begin{array}{l}\text { B2, } \\
\text { Sungai } \\
\text { Lilin }\end{array}$ & $\begin{array}{l}\text { B3, } \\
\text { Kayu } \\
\text { Agung }\end{array}$ & $\begin{array}{l}\text { D2, } \\
\text { Babat } \\
\text { Toman }\end{array}$ & Mendis & $\begin{array}{l}\text { Pulau } \\
\text { Gading }\end{array}$ & $\begin{array}{l}\text { B1, Senayar } \\
\text { Jaya }\end{array}$ \\
\hline 3 & $\begin{array}{l}\text { Bla } \\
\text { Rdt } \\
\text { Llm }\end{array}$ & $\begin{array}{l}\text { B3, } \\
\text { Kayu } \\
\text { Agung }\end{array}$ & $\begin{array}{l}\text { D2, } \\
\text { Babat } \\
\text { Toman }\end{array}$ & Mendis & $\begin{array}{l}\text { Pulau } \\
\text { Gading }\end{array}$ & $\begin{array}{l}\text { B1, } \\
\text { Senayar } \\
\text { Jaya }\end{array}$ & $\begin{array}{l}\text { B2, Sungai } \\
\text { Lilin }\end{array}$ \\
\hline 4 & $\begin{array}{l}\text { Ndn } \\
\text { Bhr } \\
\text { Lli }\end{array}$ & $\begin{array}{l}\text { D2, } \\
\text { Babat } \\
\text { Toman }\end{array}$ & Mendis & $\begin{array}{l}\text { Pulau } \\
\text { Gading }\end{array}$ & $\begin{array}{l}\text { B1, } \\
\text { Senayar } \\
\text { Jaya }\end{array}$ & $\begin{array}{l}\text { B2, } \\
\text { Sungai } \\
\text { Lilin }\end{array}$ & $\begin{array}{l}\text { B3, } \\
\text { Kayu } \\
\text { Agung }\end{array}$ \\
\hline 5 & $\begin{array}{l}\text { Sgy } \\
\text { Stp } \\
\text { Mhd }\end{array}$ & Mendis & $\begin{array}{l}\text { Pulau } \\
\text { Gading }\end{array}$ & $\begin{array}{l}\text { B1, } \\
\text { Senayar } \\
\text { Jaya }\end{array}$ & $\begin{array}{l}\text { B2, } \\
\text { Sungai } \\
\text { Lilin }\end{array}$ & $\begin{array}{l}\text { B3, Kayu } \\
\text { Agung }\end{array}$ & $\begin{array}{l}\text { D2, } \\
\text { Babat } \\
\text { Toman }\end{array}$ \\
\hline 6 & $\begin{array}{l}\text { Bbm } \\
\text { Koo } \\
\text { KJn }\end{array}$ & $\begin{array}{l}\text { B1, } \\
\text { Senayar } \\
\text { Jaya }\end{array}$ & $\begin{array}{l}\text { B2, } \\
\text { Sungai } \\
\text { Lilin }\end{array}$ & $\begin{array}{l}\text { B3, } \\
\text { Kayu } \\
\text { Agung }\end{array}$ & $\begin{array}{l}\text { D2, } \\
\text { Babat } \\
\text { Toman }\end{array}$ & Mendis & $\begin{array}{l}\text { Pulau } \\
\text { Gading }\end{array}$ \\
\hline 7 & $\begin{array}{l}\text { Smt } \\
\text { Rdw } \\
\text { Kml }\end{array}$ & $\begin{array}{l}\text { B2, } \\
\text { Sungai } \\
\text { Lilin }\end{array}$ & $\begin{array}{l}\text { B3, } \\
\text { Kayu } \\
\text { Agung }\end{array}$ & $\begin{array}{l}\text { D2, } \\
\text { Babat } \\
\text { Toman }\end{array}$ & Mendis & $\begin{array}{l}\text { Pulau } \\
\text { Gading }\end{array}$ & $\begin{array}{l}\text { B1, Senayar } \\
\text { Jaya }\end{array}$ \\
\hline
\end{tabular}

Sumber: Jadwal Divisi Akomodasi Tanaman, Olahan Penulis (2019)

Berdasarkan hasil wawancara dengan beberapa karyawan CV Fatih Terang Purnama mengenai permasalahan yang ada bahwa karyawan merasakan kelelahan karena lokasi perkebunan yang sangat jauh dari rumah dengan waktu tempuh rata-rata satu hingga tiga jam perjalanan. Adharsyah (2019) menerangkan bahwa harga sawit mengalami penurunan yang diakibatkan oleh produksi sawit Indonesia dan Malaysia yang terus meningkat dengan permintaan yang tidak sepadan. Hal tersebut berpengaruh kepada CV Fatih Terang Purnama terkait pembagian gaji yang dirasa kurang memuaskan dengan beban kerja yang diemban oleh pekerja dikarenakan kondisi harga sawit yang terus menurun dan fluktuatif. Selain itu terdapat permasalahan lain yang dialami oleh karyawan adalah kondisi lapangan kerja yang cukup menguras tenaga yaitu harus siap dengan perubahan kondisi cuaca baik saat terik dan saat hujan. 
Menurut Akhtar et al. (2018) menyatakan bahwa stres kerja sangat terkait dengan kepuasan kerja karena stres merupakan prediktor utama kepuasan kerja dan situasi stres dapat menimbulkan kemalasan pada karyawan. Seperti penelitian yang dilakukan oleh Berdasarkan penelitian terdahulu yang dilakukan Gofur (2018) dengan objek penelitian karyawan pada salah satu direktorat di Kementrian Negara bahwa stres kerja berpengaruh signifikan negatif terhadap kepuasan kerja. Hasil dari penelitian ini bahwa stres kerja berpengaruh signifikan negatif terhadap kepuasan kerja.

\section{Rumusan Masalah}

Berdasarkan latar belakang yang telah dijelaskan pada sebelumnya maka dapat disimpulkan pertanyaan penelitian sebagai berikut:

1. Bagaimana tingkat stres kerja karyawan CV Fatih Terang Purnama?

2. Bagaimana tingkat kepuasan kerja karyawan CV Fatih Terang Purnama ?

3. Bagaimana pengaruh stress kerja terhadap kepuasan kerja karyawan CV Fatih Terang Purnama?

\section{Tujuan Penelitian}

Tujuan yang ingin dicapai dalam penelitian ini adalah sebagai berikut :

1. Mengetahui tingkat stres kerja karyawan CV Fatih Terang Purnama.

2. Mengetahui tingkat kepuasan kerja karyawan CV Fatih Terang Purnama.

3. Mengetahu bagaimana pengaruh stress kerja terhadap kepuasan kerja karyawan CV Fatih Terang Purnama.

\section{KAJIAN PUSTAKA \\ Perilaku Organisasi}

Menurut Sunyoto dan Burhanudin (2015) prilaku organisasi adalah bidang studi yang mempelajari pengaruh yang diberikan oleh individu, kelompok dan stuktur terhadap perilaku dalam organisasi. Menurut Triatna (2015) perilaku organisasi berfokus pada bagaimana membuat setiap individu terbiasa bekerja dalam tim kerja yang efektif. Pendapat lain mengenai perilaku organisasi menurut Mulyadi (2016) adalah aktualisasi dari setiap wawasan yang dimiliki setiap individu dialam organisasi. Pangarso (2016) mengungkapkan bahwa perilaku organisasi dapat mempelajari pengaruh dari perseorangan, kelompok dan stuktur untuk memenuhi keefektifan dalam organisasi. Setiap orang didalam organisasi akan menerapkan pengetahuannya guna memperbaiki keefektifan organisasi Hamirul (2016).

\section{Stres Kerja}

Perusahaan perlu mengerti mengenai stres yang dialami oleh karyawannya dan bagaimana cara mengantisipasinya. Menurut Suryani et al. (2019) menjelaskan bahwa stres kerja adalah salah satu bidang yang menjadi perhatian utama didalam organisasi yang merepresentasikan sebagai akibat dari desakan berbagai permasalahan yang dihadapi oleh setiap individu didalam organisasi. Kaswan (2018) mendefenisikan stres sebagai reaksi terhadap suatu keadaan aspek umum yang sedang dialaminya seperti kepuasan terhadap pekerjaanya. Menurut Vanchapo (2020) stres kerja adalah suatu 
keadaan emosional yang dapat ditimbulkan karena adanya ketidaksesuaian beban kerja dengan kemampuan individu dalam menghadapi stres.

\section{Kepuasan Kerja}

Menurut Lantara dan Nusran (2019) kepuasan kerja merupakan sikap yang positif seorang individu terhadap pekerjaannya yang dapat ditimbulkan berdasarkan penilaian terhadap situasi kerja sesuai dengan aspek pekerjaannya sehingga seseorang dapat relatif puas dengan salah satu aspek dan tidak puas dengan aspek lainnya. Pendapat lain mengenai pengertian kepuasan kerja yang diungkapkan oleh Fattah (2017) adalah semakin banyak aspek aspek dalam pekerjaan yang selaras dengan harapan individu pada organisasi maka semakin tinggi tangkat kepuasan yang dirasakannya, sebaliknya jika semakin sedikit aspek dalam pekerjaan yang selaras dengan harapan individu dalam perusahaan maka semakin rendah tingkat kepuasan yang dirasakan.

\section{Kerangka Pemikiran}

\section{Gambar 1. Kerangka Pemikiran}

\begin{tabular}{|c|c|}
\hline $\begin{array}{l}\quad \text { Stres kerja } \\
\qquad(\mathrm{X}) \\
\text { 1. Faktor Stres } \\
\text { Lingkungan Luar } \\
\text { 2. Faktor Stres } \\
\text { Lingkungan Organisasi } \\
\text { 3. Faktor Stres Kerja } \\
\text { Individu } \\
\text { (Gilang et al. 2015) }\end{array}$ & $\begin{array}{l}\qquad \begin{array}{l}\text { Kepuasan Kerja } \\
\qquad(\mathrm{Y})\end{array} \\
\text { 1. Salary and Walfare } \\
\text { 2. Work it Self } \\
\text { 3. Leader Behaviour } \\
\text { 4. Personal Growth } \\
\text { 5. Interpersonal Relationship } \\
\text { 6. Job Competence } \\
\text { (Lee et al. 2017) }\end{array}$ \\
\hline
\end{tabular}

Sumber: Hasil Olahan Penlis (2019)

$\mathrm{H} 0=$ Stres kerja tidak berpengaruh signifikan negatif terhadap kepuasan kerja karyawan CV Fatih Terang Purnama

$\mathrm{H} 1=$ Stres kerja berpengaruh signifikan negatif terhadap kepuasan kerja karyawan CV Fatih Terang Purnama

\section{METODE PENELITIAN \\ Jenis Penelitian}

Metode penelitian yang akan digunakan adalah metode kuantitatif. Menurut Sahu dan Singh (2016:7) metode kuantitatif merupakan penelitian yang didasarkan pada pengukuran suatu fenomena yang dianalisis menggunakan statistik yang melihat kemungkinan kaitan atau hubungan antar variabel. Pada metode kuantitatif fenomena dijelaskan menggunakan data numerik (Grant et al., 2017: 5).

Jenis penelitian ini adalah penelitian deskriptif dan penelitian kausal. Menurut Sekaran dan Bougie (2017:111) menjelaskan bahwa pada penelitian deskriptif data yang didepskrisikan adalah karakteristik dari manusia, peristiwa dan situasi. Sedangkan penelitian kausal merupakan variabel yang dapat mempengaruhi variabel lain atau hasil (Trhocim et al., 2015:4). Penelitian ini memiliki tujuan untuk 
mengetahui tingkat stres kerja dan kepuasan kerja karyawan pada perusahaan yang bergerak pada bidang perkebunan kelapa sawit. Maka pada penelitian ini, peneliti akan mencari tahu apakah ada pengaruh stres kerja terhadap kepuasan kerja.

Berdasarkan waktu pelaksanaannya peneliti menggunakan cross sectional design. Menurut Kumar (2019:174) cross sectional design merupakan waktu pelaksanaan penelitian yang digunakan untuk mengetahui perubahan dalam fenomena atau variabel antara dua titik dalam waktu penelitian yang bersamaan. Dengan menggunakan waktu pelaksanaan cross sectional design dapat mempermudah peneliti untuk mengumpulkan data yang diperlukan dengan pelaksanaan waktu yang bersamaan, sehingga membantu peneliti untuk mempercepat penggumpulan data.

\section{Tempat dan Waktu Penelitian}

Penelitian dilaksanakan pada perusahaan CV Fatih Terang Purnama, yang berlokasi di Sekayu, Musi Banyuasin, Sumatera Selatan. Sedangkan waktu pelaksanaan dilakukan mulai dari bulan Januari 2019 hingga bulan April 2020.

\section{Populasi dan Sampel}

Populasi merupakan kelompok yang akan menjadi perhatian bagi peneliti dan akan didapatkan sebuah hasil (Hermawan, 2019:61). Maka yang akan menjadi populasi dalam penelitian ini adalah karyawan CV Fatih Terang Purnama yang berkaitan dengan variabel penelitian ini terdapat populasi 160 karyawan yang ada. Pada penelitian ini menggunakan non probability sampling dengan kategori purposive sampling. Menurut Sahu dan Singh (2016:116) non probability sampling adalah tidak ada kemungkinan dikaitkan dengan seseprang yang dipulih, kerangka sampling tidak dikembangkan, tidak ada karakteristik dan keterwakilan sampel tetapi menggunakan Teknik yang dianggap sesuai dengan tujuan penelitian. Sedangkan purposive sampling menurut Sugiyono (2016:85) adalah teknik penentuan sampel dengan pertimbangan tertentu. Alasannya karena adanya keterjangkauan untuk meneliti seluruh responden yang ada.

\section{Teknik Pengumpulan Data}

Teknik pengumpulan data merupakan suatu cara khusus yang dilakukan oleh peneliti untuk tujuan mencari data yang akan diperlukan dalam penelitian (Hamdi \& Bahruddin, 2015:47). Pada penelitian ini yaitu teknik yang digunakan adalah dengan metode kuisioner menurut Bungin (2016:130) adalah serangkaian kumpulan pernyataan yang telah disusun secara sistematis sesuai dengan kebutuhan dalam daftar pertanyaan dan diberikan kepada responden untuk mengisinya.

\section{Teknik Analisis}

Analisis deskriptif dapat digunakan apabila peneliti sudah mengetahui faktor atau variabel apa yang akan digunakan untuk mengukur sebuah objek. Menurut pendapat Indrawati (2015:115) pada penelitian ini menggunakan analisis deskriptif untuk mendeskripsikan variabel (X) Stres Kerja dan (Y) Kepuasan kerja dengan bantuan kuisioner. 
Selanjutnya untuk melihat hasil dari nilai korelasi yang diperoleh dapat dibuktikan dengan tabel sebagai berikut :

Tabel 2. Interpretasi Korelasi

\begin{tabular}{|l|l|}
\hline Interval & Tingkat Hubungan \\
\hline $25 \%-43,75 \%$ & Sangat Rendah \\
\hline$>43,75 \%-62,5 \%$ & Rendah \\
\hline$>62,5 \%-81,25 \%$ & Tinggi \\
\hline$>81,25 \%$ & Sangat Tinggi \\
\hline
\end{tabular}

Sumber : Data Primer, diolah (2019)

\section{Pengujian Hipotesis}

Menurut Indrawati (2015:105) Hipotesis yaitu Ho dan H1.Ho yang memberikan penyataan keputusan untuk menolak sedangkan H1 memberikan pernyataan bahwa keputusan diterima. Penelitian ini menggunakan uji $t$ yang digunakan untuk mengetahui tingkat signifikan variabel bebas terhadap variabel terikat, jika $\mathrm{t}$ tabel $<\mathrm{t}$ hitung maka variabel bebas memberikan pengaruh yang signifikan terhadap variabel terikat, ketika nilai signifikansinya $>0,05$ maka $\mathrm{H} 0$ diterima dan jika nilai signifikansinya <0,05 maka H0 ditolak (Ghozali, 2013:99).

Ho

Stres kerja tidak berpengaruh signifikan negatif terhadap kepuasan kerja pada karyawan CV Fatih Terang Purnama

Stres kerja berpengaruh signifikan negatif terhadap kepuasan kerja pada

$\mathrm{H} 1$ karyawan CV Fatih Terang Purnama

\section{HASIL PENELITIAN DAN PEMBAHASAN Hasil Penelitian}

Perhitungan uji asumsi klasik pada penelitian ini menggunakan Service Solution (SPSS). Uji asumsi klasik yang dilakukan terdiri dari perhitungan uji normalitas, uji hetrokedastisitas. Berdasarkan hasil penelitian yang dilakukan dapat diketahui bahwa nilai Asymp. Sig (2-tailed) adalah sebesar 0.095. karena hasi yang diperoleh sebesar $0.095>0.005$ maka dianggap berdistribusi normal. Berdasarkan hasil uji heterokedatisitas di dapat nilai sig: 0.647 maka dianggap tidak terjadi heterokedastisitas karena nilai sig $>0.005$. Sehingga jika varian dari residual satu pengamatan ke pengamatan lainnya tetap, maka disebut homoskedastisitas. Sehingga penelitian ini dapat dilanjutkan.

Tabel 3. Regresi Linier Sederhana

\begin{tabular}{|l|l|l|l|l|}
\hline \multicolumn{2}{|l|}{ Model } & B & T & Sig. \\
\hline \multirow{2}{*}{1} & (Constant) & 152.041 & 28.826 & 0.000 \\
\cline { 2 - 5 } & Stres Kerja & -.885 & -11.008 & 0.000 \\
\hline
\end{tabular}

Dependent Variable: Kepuasan Kerja

Sumber: Hasil Penelitian, diolah (2020)

Dari persamaan di atas dapat diuraikan sebagai berikut:

1. Nilai konstanta sebesar 152.041, yang mengandung arti bahwa nilai konstanta jika stres kerja bernilai 0 (nol) dan tidak ada perubahan, maka kepuasan kerja akan tetap bernilai sebesar 152.041 . 
2. Koefisien regresi $X$ yang merupakan variabel independent, yaitu sebesar -0.885 menyatakan bahwa setiap perubahan $1 \%$ nilai dari stres kerja, maka nilai variabel kepuasan kerja akan berkurang sebesar -0.885 . Koefisien regresi tersebut bernilai negatif, sehingga arah pengaruh stres kerja terhadap kepuasan kerja adalah negatif.

Tabel 4. Uji T

\begin{tabular}{|l|l|l|l|l|}
\hline \multicolumn{2}{|l|}{ Model } & B & T & Sig. \\
\hline \multirow{2}{*}{1} & (Constant) & 152.041 & 26.826 & 0.000 \\
\cline { 2 - 5 } & Stres Kerja & -.885 & -11.008 & 0.000 \\
\hline
\end{tabular}

Dependent Variable: Kepuasan Kerja

Sumber: Hasil Penelitian, diolah (2020)

Berdasarkan hasil pengujian hipotesis dengan uji t pada tabel 4.7 diatas, diperoleh hasil $\mathrm{t}$ hitung sebesar -11.008 dengan signifikansi sebesar 0.000, selanjutnya dibandingkan dengan $\mathrm{t}$ tabel dengan probabilitas $5 \%$ dan $\mathrm{df}=160$ $1=159$, maka diperoleh hasil $\mathrm{t}$ tabel sebesar 1.975, dikarenakan hasil thitung -11.008 $>$ ttabel 1.975 dan signifikansi $0.000<0.05$, maka Ho ditolak dan Ha diterima, sehingga dapat dinyatatan bahwa stres kerja berpengaruh negatif signifikan terhadap kepuasan kerja pada karyawan CV. Fath Terang Purnama. Dari hasil pengujian hipotesis tersebut, maka dapat digambarkan kurva uji t, sebagai berikut:

Tabel 5. Kurva Uji T

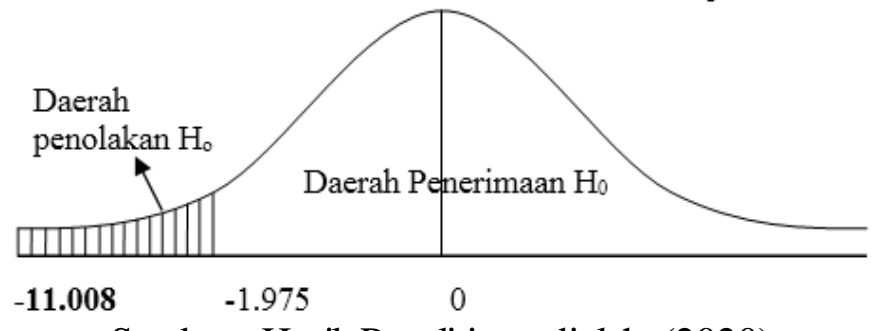

Sumber: Hasil Penelitian, diolah (2020)

\section{Pembahasan}

Berdasarkan tanggapan responden yang telah dianalisa sebelumnya variabel stress kerja memiliki presentase sebesar $55,55 \%$ berdasarkan garis kontinum termasuk kategori rendah. Berdasarkan tiga dimensi untuk variabel stress kerja yaitu faktor stres kerja lingkungan luar yang memiliki hasil tertinggi sebesar $70.00 \%$ dengan kategori tinggi. Sedangkan hasil terendah sebesar $48.13 \%$ dengan kategori rendah. Dimensi selanjutnya faktor stres kerja organisasi yang memiliki hasil tertinggi sebesar $54.69 \%$ dengan kategori rendah. Sedangkan untuk hasil yang terendah pada dimensi ini sebesar $44.22 \%$ dengan kategori rendah. Selanjutnya pada dimensi faktor stres kerja individu yang memiliki hasil tertinggi dengan presentase sebesar $80.78 \%$ masuk kedalam kategori tinggi. Sedangkan untuk hasil terendah dengan presentase sebesar $45.78 \%$ masuk kedalam kategori rendah.

Sedangkan pada variabel dependent kepuasan kerja, diperoleh hasil dari tanggapan responden memiliki presentase sebesar $75.03 \%$ dan masuk pada kategori tinggi. Variabel kepuasan kerja memiliki lima dimensi yaitu salry and walfare leader behaviour, personal growth, interpersonal relationship dan job competence. Pada dimensi salary and walfare yang memiliki hasil tertinggi sebesar $83.75 \%$ dengan 
kategori sangat tinggi dan untuk hasil terendah sebesar $73.91 \%$ dengan kategori tinggi. Selanjutnya dimensi leader behavior, hasil tertinggi sebesar $80.74 \%$ kategori tinggi dan hasil terendah sebesar $73.75 \%$ kategori tinggi. Selanjutnya dimensi personal growth yang memiliki hasil tertinggi sebesar $82.50 \%$ sangat tinggi dan hasil $70.63 \%$ atau tinggi. Dimensi interpersonal relationship yang memiliki hasil tertinggi $81.09 \%$ kategori tinggi dan hasil terendah $63.75 \%$ tinggi. Dimensi job competence hasil tertinggi sebesar $64.38 \%$ dengan kategori tinggi dan hasil terendah $63.28 \%$ dengan kategori tinggi.

Pengujian hipotesis yang dilakukan bertujuan untuk mengetahui apakah stres kerja memiliki pengaruh terhadap kepuasan kerja pada CV Fath Terang Purnama. Berdasarkan nilai t, dapat diketahui bahwa -11.008> ttabel 1,967 dan signifikansi $0.000<0.05$, maka Ho ditolak. Sedangkan dari persamaan regresi linier sederhana, nilai konstanta variabel stres kerja yang diperoleh mengartikan bahwa koefisiennya bernilai negatif, sehingga dapat dinyatakan bahwa stres kerja berpengaruh negatif signifikan terhadap kepuasan kerja. uji koefisien determinasi (R2) sebesar 0.434 jadi variabel stres kerja memiliki kontribusi pengaruh sebesar $43.4 \%$ pada kepuasan kerja. Hasil koefisien korelasi $(\mathrm{R})$ memperoleh nilai 0.659 yang artinya tergolong kuat.

\section{KESIMPULAN DAN SARAN \\ Kesimpulan}

Berdasarkan hasil penelitian yang telah dikemukakan oleh penulis bertujuan untuk mengetahui tingkat stres kerja dan kepuasan kerja karyawan CV Fatih Terang Purnama serta mengetahui pengaruh stress kerja terhadap kepuasan kerja karyawan CV Fatih Terang Purnama. Maka dapat disimpulkan kesimpulan sebagai berikut:

1. Stres kerja pada CV Fatih Terang Purnama tergolong dalam tingkatan yang rendah. Menyangkut hal tersebut CV Fatih Terang Purnama tetap mengelola stress kerja dengan baik karena ketika sebuah perusahaan tidak mengelola stres kerja dengan baik hal tersebut akan memberikan dampak yang menjadi hambatan karyawab dalam melakukan pekerjaan dan pada akhirnya tujuan yang diinginkan perusahaan tidak tercapai.

2. Kepuasan kerja pada CV Fatih Terang Purnama tergolong kedalam tingkatan yang tinggi. Hal tersebut dikarenalam para karyawan sudah merasa kebutuhan telah terpenuhi dengan baik. Dengan demikian perusahaan harus tetap menjga kepuasan yang dirasakan oleh karyawannya

3. Hasil yang diperoleh dalam penelitian ini adalah stres kerja berpengaruh signifikan negatif pada karyawan CV Fatih Terang Purnama. Hal ini memiliki makna semakin tinggi stress kerja akan semakin menurunkan kepuasan kerja, begitu juga sebaliknya semakin rendah stres kerja akan semakin meningkatkan kepuasan kerja.

\section{Saran}

Berdasarkan kesimpulan diatas, penulis dapat memberikan beberapa saran sebagai berikut :

1. Bagi perusahaan hendaknya menambah mes disetiap titik area perkebunan guna memberikan fasilitas dalam melakukan istirahat dikarenakan antar perkebunan satu dengan yang lainnya memiliki jarak yang relatif jauh sehingga dapat meminimalisir 
kelelahan yang dirasakan oleh karyawan. Hal tersebut perlu dilakukan karena mencegah ketidakpuasan dalam bekerja. Maka dari itu karyawan yang melakukan mobilisasi area perkebunan merasa beban pekerjaan yang diterima tidak terlalu menimbulkan kelelahan dalam bekerja.

2. Bagi peneliti selanjutnya Diharapkan untuk penulis selanjutnya dapat meneliti lebih dari dua variabel independent dan dependent yaitu variabel stress kerja dan kepuasan kerja. Sehingga diharapkan peneliti selanjutnya dapat mengembangkan penelitian ini dengan menambah variabel terkait dengan stres kerja dan kepuasan kerja.

\section{DAFTAR PUSTAKA}

Adharsyah, T. 2019. Sebabkan Defisit Parah, Ini Empat Alasan CPO Terjun Bebas. [online].https $/ /$ www.cnbcindonesia.com/market/20190516150147-1772967/sebabkan-defisit-parah-ini-4-alasan-harga-cpo-terjun-bebas[17 September 2019]

Agus Harjito dan Martono. 2011. Manajemen Keuangan. Edisi 2. Cetakan Pertama. Penerbit EKONESIA. Yogyakarta.

Akhtar, Adeel, Naheed, K., Akhtar, S., \& Farooq, U. 2018. Impact of Job Stress on Employees' Job Satisfaction: An Empirical Study of Pakistan of Private Banksof Pakistan. Pakistan Journal of Social Science, 28 (1), 137-151. Retrieved from Pakistan Journal of Social Science.

Anjungsoro, F. 2016. Tingkat Kepuasan Kerja di Google Indonesia Kalahkan Miscrosoft. [online]. http://www.tribunnews.com/techno/2016/05/17/tingkatkepuasan-kerja-di-google-indonesia-kalahkan-microsoft [16 Februari 2019]

Bungin, H. M. 2016. Metodelogi Penelitian Sosial dan Ekonomi: Format-format Kuantitatif dan Kualitatif untuk Studi Sosiologi, Kebijakan Publik, Komunikasi, Manajemen dan Pemasaran. Jakarta: Kencana Penada Media Group.

Daud, N. 2016. Determinant of Job Satisfaction: How Satisfied are The New Generation Employess in Malaysia, Journal Social and Behavioral Science, 219, 208-213. Retrieved from Science Direct.

Fattah, H. 2017. Kepuasan Kerja dan Kinerja Pegawai. Yogyakarta: Penerbit Elmatera.

Gilang, A., Wanara. B., Pangarso. A. 2015. Analisis Stres Kerja Karyawan Pada PT Pikiran Rakyat. Jurnal Manajemen Indonesia, 15 (3), 195-206.

Gofur, A. 2018. Pengaruh Stres Kerja Terhadap Kepuasan Kerja Pegawai. Jurnal Riset dan Bisnis (JRMB), 3(S1), 295-304. Retrived from Researchgate.net.

Hamdi, A.S., \& Bahruddin, E. 2015. Metode Penelitian Kuantitatif Aplikasi dalam Pendidikan. Yogyakarta: Deepublish

Hamirul. 2016. Perilaku Organisasi. Padang: Universitas Putera Indonesia.

Hermawan, I. 2019. Metodologi Penelitian Pendidikan. (Kualitatif, Kuantitatif dan Mixed Method). Kuningan: Penerbit Hidayatul Quran.

Indrawati. 2015. Metodologi Penelitian Manajemen dan Bisnis Konvergensi Teknologi Komunikasidan Informasi. Bandung: PT Riefka Aditama.

Kaswan, M.M. 2018. Perilaku Organisasi Positif. Bandung: CV Pustaka Setia. 
Kumar, R. 2019. Research Methodology a Step by Step Guide for Beginners. New Delhi: SAGE Publication.

Lee, X., Yang, B., \& Li, W. 2017. The Influence Factor of Job Satisfaction and its relationship with turnover intention. The Business and Manajemen Review, 33(3), 697-707. Retrieved from Research Gate. British Medical Journal. Retrieved from BMJ Open.

Lantara, D., \& Nusran, M. 2019. Dunia Industri: Prespektif Tenaga Kerja. Makassar: Nas Media Pustaka

Mahartika, L. 2019. Tujuan Manajemen Sumber Daya Manusia, Berikut Pengertian

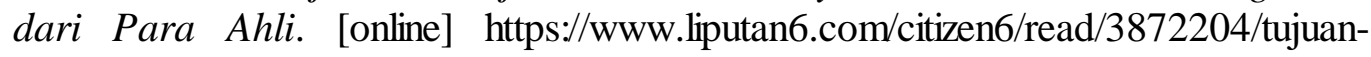
manajemen-sumber-daya-manusia-berikut-pengertian-dari-para-ahli Februari 2019]

Mulyadi, D. 2015. Perilaku Organisasi dan Kepemimpinan Pelayanan. Bandung: Alfabeta.

Novita, Sunuharjo, B.S., \& Ruhana, I. 2016. Pengaruh Kepuasan Kerja dan Komitmen Organisasional Terhadap Kinerja Karyawan (Studi Pada PT. Telekomumikasi Indonesia Tbk Witel Jatim Selatan, Malang). Jurnal Administrasi Bisnis,34(1), 38-46. Retrieved from Jurnal Adminitrasi Bisnis.

Nugraha, I. 2019. Menyoal Nasib Buruh Kelapa Sawit di Indonesia. [Online]. https://www.mongabay.co.id/2019/05/01/menyoal-nasib-buruh-perkebunansawit-di-indonesia/ . 3 September 2019.

Pangarso, A. 2016. Perilaku Organisasi. Yogtakarta: Penerbit Deepublish.

Praditya, I.I. 2018. UMN Cetak SDM Unggul dan Siap Bersaing di Era Industri. [online]. https $/ /$ www.liputan6.com/bisnis/read/3574611/umn-cetak-sdm-ungguldan-siap-bersaing-di-era-ind ustri-40 [5 Februari 2019]

Riandy. 2016. Pengaruh Stres Kerja Terhadap Kinerja Karyawan Pada PT Borneo Laboratorium Inspeksi dan Surveyor Service di Samarinda. E-Journal Administrasi Bisnis, 4(4), 1059-1072. Retrieved from e-journal UNMUL (Universitas Mulawarman).

Riaz, M., Ahmad, N., IT, M., Murtaza, G., Khan, T., \& Firdous, H. 2016. Impactof Job Stress on Employee Job Satisfaction. International Review of Management and Business Research, 5(4), 1370-1382. Retrieved from International Review of Management and Business Research.

Sahu, S.K., \& Singh, T.J. 2016. Research Methodology. Agra: SBPD Publication.

Salisu, J. B., Chinyio, E., \& Suresh, S. 2015. The Impact of Compensation on the Job Satisfaction of Public Sector Construction Workers of Jigawa State of Nigeria. The business and Management Review, 6(4), 282-296. Retrieved from The business and Management Review.

Sekaran,U., \& Bougie, R. 2017. Metode Penelitian untuk Bisnis. Jakarta Selatan: Salemba Empat.

Sugiyono. 2016. Metode Penelitian Kuantitatif, Kualitatif dan R\&D. Bandung: Penerbit alfabeta.

Suryani, N.K., Laksemini, K.D.I.S., \& Ximenes, M. 2019. Buku Ajar Perilaku Organisasi. Bali: Penerbit Nilacakra. 
Sunyoto, D., \& Burhanudin. 2015. Teori Perilaku Organisasi. Yogyakarta: CAPS (Center of Academic Publishing Service).

Trhocim, W.M., Donnelly., \& Arora, K. 2015. Research Methods The Essential Knowledge Base. Boston: Cangage Learning.

Triatna, C. 2015. Perilaku Organisasi dalam Pendidikan. Bandung: PT Remaja Roesdakarya.

Vanchapo, A.R. 2020. Beban Kerja dan Stres Kerja. Pasuruan: Penerbit Qiara Media.

Wartono, T. 2017. Pengaruh Strss Kerja Terhadap Kinerja Karyawan (Studi Pada Kryawan Majalah Mother and Baby). Jurnal Ilmiah Prodi Manajemen Universitas Pamulang, 4(2), 41-55. Retrieved from e-journal UNPAM (Universitas Pamulang). 